\title{
CARBON MONOXIDE RELATED DEATHS IN ALQURAYYATE, SAUDI ARABIA FROM 2004 TO
} 2018

\author{
Medhat Galal Attaia ${ }^{\mathrm{a}}$, Ekramy Elmorsy ${ }^{\mathrm{b} . \mathrm{c}}$, Amirah Ali Alshaman ${ }^{\mathrm{d}}$, Hanaa Mohamed \\ Alzahed $^{\mathrm{d}, \mathrm{e}}$, Abdulrahman Albalawei $^{\mathrm{d}}$ \\ aForensic Medicine Center, Alqurayyate Principality health affairs, Saudi Arabia, \\ ${ }^{b}$ Forensic Medicine and Toxicology Department, Mansoura faculty of Medicine, \\ Egypt, ' Departments of Pathology, Faculty of Medicine, Northern Border University, \\ Arar, Saudi Arabia, ${ }^{d}$ Tabouk Poison Control Center, Tabouk Principality Health \\ Affairs, Saudi Arabia, e Forensic Medicine and Toxicology Department, faculty of \\ Medicine, Cairo University, Egypt. \\ Corresponding author: Dr. Ekramy Elmorsy، e-mail: ekramyelmorsy@mans.edu.eg
}

\begin{abstract}
Objectives: The current work aimed to study carbon monoxide $(\mathrm{CO})$ related deaths in Alqurayyate during the period from 2004-2018. Methods: All medico-legally examined cases with carboxyhemoglobin [COHb] levels $\geq 10 \%$, within the study years, were investigated. The demographic data, autopsy findings and toxicological laboratory results for the cases of interest were collected. Results: Among 461 autopsied cases, 52 cases [11.3\%] show carboxy-hemoglobin $(\mathrm{COHb})$ levels $\geq 10 \%$. Higher $\mathrm{COHb}$ levels were significantly more common among males, young and elderly and Saudi people [0.012, 0.009, and 0.3 respectively]. was the cause of death in 19 cases [4.1\%] while $\mathrm{CO}$ poisoning was suggested as a contributing factor in another 33 [7.2\%] deaths. The mode of deaths was mainly accidental [78.8\%]. Houses were the most common place of death [63.5\%] and most CO related deaths happened in the winter months [73.1\%]. The most common suggested source for exposure to $\mathrm{CO}$ among carbon monoxide poisoning (COP) deaths were car exhaust [36.8\%], followed by charcoal heaters [31.6\%]. Regarding autopsy findings, the external appearance revealed cherry red hypostasis in only $26.9 \%$ of CO related cases. The most common findings were pulmonary edema, cerebral edema, and congested lungs [96.2,82.7, and 80.8\% respectively]. Conclusion: COP remains a common cause of death, inspite of the safety precautions. More public awareness programs about COP are recommended. Also,
\end{abstract}


$\mathrm{COHb}$ levels should be routinely estimated in the autopsied cases, especially with suggestive history and death scene.

Keywords: Carbon monoxide poisoning; autopsy; carboxy hemoglobin; myocardial ischemia; poisoning, analytical toxicology.

\section{INTRODUCTION}

Carbon monoxide (CO) is a colorless, odorless and tasteless gas, which was estimated to be $100 \mathrm{ppb}$ in earth's atmosphere and it is considered to be the second a major atmosphere pollutant after carbon dioxide. The incomplete combustion of hydrocarbons is the main source of $\mathrm{CO}$ (Kreuzer et al., 2009). It is produced by fuel-burning appliances and devices such as water heaters, Furnaces or boilers, gas stoves, ovens, and motor vehicles. Carbon monoxide can be produced in the human body with the normal body catabolism (Raub et al., 2000). The normal level of carboxyhaemoglobin $(\mathrm{COHb})$ can be about $0.5 \%$ with normal variations among individual. Its level can be elevated up to $15 \%$ in among heavy smokers. Levels of $5 \%$ were found in patients with hemolytic anemia and pregnant ladies (Lippi et al., 2012).

Exposure to $\mathrm{CO}$ is fatal and can lead to death due to conversion of hemoglobin to $\mathrm{COHb}$ with significant tissue hypoxia as the affinity of hemoglobin to CO is $220-240$ times its affinity to oxygen. This leads to less oxygen carrying capacity of hemoglobin and lower release of oxygen to the tissues with marked tissue hypoxia (Varon et al., 1999). The brain and heart are the main organs affected by $\mathrm{CO}$ poisoning (COP). The symptoms of carbon monoxide poisoning are non-specific and varied, and include headache, fatigue, visual disorders, cardiac palpitation, chest pain, coma and syncope with more morbidities and mortalities in people suffering other cardiac disorders (Hampson and Weaver, 2007). Poisoning by $\mathrm{CO}$ is mostly underdiagnosed because of the varied nonspecific manifestations. However, it is estimated that at least 40000 COP cases are attending to the American Emergency departments annually (Ghosh et al., 2015). While it was reported that 5312 cases of $\mathrm{CO}$ poisoning were diagnosed in British hospitals within 10 years from 20002010 (Cobb and Etzel, 1991).

Carbon monoxide poisoning is a major cause of death worldwide. Several safety precautions were considered to decrease $\mathrm{CO}$ deaths with much more decrease in $\mathrm{CO}$ mortality rates (Sircar et al., 2015). However, CO was reported to be the second most common nonmedicinal poisoning mortalities in the United states from 1999-2012 (Statista, 2017)The Centers of Disease Control and Prevention (CDC) estimated that $\mathrm{CO}$ was a contributing cause of death in 16,447 cases during the period 1999-2004, with 2,631 deaths were unrelated to fires (CDC, 2007) While 715 deaths were reported in England due to unintentional $\mathrm{CO}$ poisoning in the period from 1995-2016 (Aldossary et al., 2015) Global data regarding Saudi Arabia CO deaths are not clear. The forensic chemistry laboratory in Dammam (Eastern province) had reported $\mathrm{CO}$ poisoning in 68 autopsied cases during the period from 2004-2013 among 894 autopsied cases (de Juniac et al., 2012). Carbon monoxide deaths are mostly accidental; however, other suicidal and homicidal were also reported (Lippi et al., 2012). Some cases showed higher mortalities due to 
CO poisoning coronary heart diseases, anemia, pregnant women and their fetus and infants, and the elderly (Mehta et al., 2001)

In autopsied cases died due to $\mathrm{CO}$ poisoning certain neuroanatomical injuries can be found as white matter damage, atrophied globus pallidus, hippocampus, thalamus and cerebral cortex (Zhu et al., 2006). Myocardial ischemic changes and elevated cardiac biomarkers also can be found as increased creatinine kinase $\mathrm{MB}$ and troponin (Battah et al., 2009). As autopsy and chemical analysis are the most trustable tools to evaluate the cause of death, the current study aimed to analyze the cases which gave positive results for $\mathrm{CO}$ in Alqurayyate during the period from 2004 to 2018. All demographic data, the circumstances and the laboratory data were considered.

\section{MATERIALS AND METHODS}

Ethical issues: The study was conducted and the data were accessed after a formal permission form he central administration of Forensic medicine in Riyadh

Study designs; According to laws in Saudi Arabian, all suspected unnatural deaths are notified to the police for further investigations about the cause of death and any possibility of homicide The current study is a retrospective study for autopsied cases in Qurayyat (a city located in Al Jawf Province, in northern Saudi Arabia) during the years' period from January 2004 till December 2014, then prospective study was conducted for cases of interest from January 2014 till December 2018. All cases with $\mathrm{COHb}$ $\geq 10 \%$ were evaluated considering all data from police reports, scenes of death, autopsy reports, and toxicological reports. Demographic data including sex, age, and nationality were collected. Manner of death, place of death, suggested source of carbon monoxide and the season at which the studied cases were recorded for further analysis. For all cases the medico legal autopsy included systematic analysis for the different body organs with samples obtained [blood, urine liver, kidney, stomach, stomach content, lung, brain bladder, intestine] for toxicological evaluation. Tissue sections were obtained for histopathologic examination.

Analytic method; Toxicological samples were analyzed for $\mathrm{COHb}$, ethanol, illicit drugs [Amphetamine, barbiturates, benzodiazepine, cannabis, cocaine, and opiates] and pesticide. Carboxyl hemoglobin level was analyzed on Ultraviolet system following Lucini et al. (2009). Whole blood preserved on EDTA was used. To measure $\mathrm{COHb}$, one to three drops of case sample were added to a $1 \mathrm{~cm}$ cuvette containing $2-3 \mathrm{ml}$ of $0.5 \%$ ammonia solution. Reference sample [blank] was prepared by adding $2-3 \mathrm{ml}$ of $0.5 \%$ ammonia solution to a $1 \mathrm{~cm}$ cuvette without blood. At least one positive and one negative control samples were analyzed with each group of case samples. The absorbance of the solution is scanned at wave length 650 $\mathrm{nm}$ to $500 \mathrm{~nm}$ on Ultraviolet system. The absorbance ratio at A541nm /A555 $\mathrm{nm}$ is calculated and the percent $\mathrm{COHb}$ is determined for the negative, positive control samples and the case samples from the slope of the known calibration curve. Calibration curve was obtained by saturating negative blood with known concentrations of $\mathrm{COHb}$.

Statistical analysis; The data were processed and analyzed by GraphPad Prism V (GraphPad Software Inc., San Diego, CA). Chi square was used for analysis of the categorical data. Data were represented as a percentage of the totals. Significance was considered with $p$-value $<0.05$. 


\section{RESULTS}

During the study years, 461 cases were autopsied [378 $(81.9 \%)$ males and $83(18.1 \%)$ females]. Among them, 54 cases $(11.7 \%)$ show $\mathrm{COHb}$ levels $>10 \%$. The distribution of cases over the study years is shown in Table (1).

Higher $\mathrm{COHb}$ levels were significantly more common among males and elderly in relation to the other autopsied cases (Table 2). CO was reported as a cause of death among 19 cases while $\mathrm{CO}$ was suggested as a contributing factor in the other 33 deaths (Table 3). Houses were the most common place of death and most deaths attributed to $\mathrm{CO}$ happened in the winter months. The mode of deaths was reported to be accidental in most of cases (Table 4).

According to the reports, the most common suggested source for exposure to Co was smoking (35.2\%) followed by fires $(27.8 \%)$ (Table 4$)$, while the source of exposure was not identified among 3 cases. Charcoal heating represented $60 \%$ of COP deaths among Saudi people.

Regarding autopsy findings, the external appearance revealed cherry red colour red hypostasis in only 14 autopsied cases. The most common findings were pulmonary edema, cerebral edema, and congested lungs $(96.2,82.7$, and $80.8 \%$ respectively).

Table 1: Distribution of CO related deaths from 2004-2018 in Alquryyat

\begin{tabular}{|c|c|c|c|c|}
\hline Year & Total autopsies & COHb>10\% & CO deaths & CO contribute in death \\
\hline 2004 & $24(100 \%)$ & $7(29.2)$ & $3(12.5)$ & $4(8.5)$ \\
\hline 2005 & $20(100 \%)$ & $1(5)$ & 0 & $1(5)$ \\
\hline 2006 & $21(100 \%)$ & $1(4.8)$ & 0 & $1(4.80$ \\
\hline 2007 & $23(100 \%)$ & $1(4.3)$ & 0 & $1(4.3)$ \\
\hline 2008 & $17(100 \%)$ & $1(5.9)$ & 0 & $1(5.9)$ \\
\hline 2009 & $20(100 \%)$ & $1(5)$ & $1(5)$ & 0 \\
\hline 2010 & $28(100 \%)$ & $1(3.6)$ & $1(3.5)$ & 0 \\
\hline 2011 & $15(100 \%)$ & $1(6.7)$ & $1(6.7)$ & 0 \\
\hline 2012 & $25(100 \%)$ & $3(12)$ & $2(8)$ & $1(4)$ \\
\hline 2013 & $20(100 \%)$ & $1(5)$ & 0 & 1 \\
\hline 2014 & $48(100 \%)$ & $2(4.2)$ & $2(4.2)$ & 0 \\
\hline 2015 & $40(100 \%)$ & $4(10)$ & $2(5)$ & $3(5.4)$ \\
\hline 2016 & $55(100 \%)$ & $6(10.9)$ & $3(5.5)$ & $6(12)$ \\
\hline 2017 & $50(100 \%)$ & $10(20)$ & $4(8)$ & $12(21.9)$ \\
\hline 2018 & $55(100 \%)$ & $14(25.5)$ & $2(3.6)$ & $33(7.2)$ \\
\hline Totals & $461(100 \%)$ & $52(11.3 \%)$ & $19(4.1 \%)$ & \\
\hline
\end{tabular}


Table 2: Effect of age, gender and nationalities on percent of $\mathrm{CO}$ related deaths among the autopsied cases. $P$-values were estimated by Chi Square test. * means $p$-value $<0.05$, while $* * *$ means $\mathrm{p}$-value $<0.001$.

\begin{tabular}{|l|c|r|c|c|l|}
\hline Variables & & Total $(\%)$ & COHb $<10$ & COHb $\geq 10$ & \multirow{2}{*}{-values } \\
\hline \multirow{3}{*}{ Gender } & Females & $83(100)$ & $80(96.4)$ & $3(3.6)$ & $0.012^{*}$ \\
\cline { 2 - 5 } & Males & $378(100)$ & $329(87.1)$ & $49(12.9 \%)$ & \\
\hline \multirow{3}{*}{ Ages (years) } & $\leq 30$ & $144(100)$ & $130(90.3)$ & $14(9.7)$ & \multirow{2}{*}{$0.0009 * * *$} \\
\cline { 2 - 5 } & $31-50$ & $309(100)$ & $290(93.9)$ & $19(6.1)$ & \\
\cline { 2 - 5 } & $>50$ & $108(100)$ & $83(81.4)$ & $19(18.6)$ & \\
\cline { 2 - 5 } & Sationalities & $285(100)$ & $260(91.2)$ & $25(8.8)$ & \multirow{2}{*}{$0.03 *$} \\
\cline { 2 - 5 } & Son-Saudi & $176(100)$ & $149(84.7)$ & $27(15.3)$ & \\
\hline
\end{tabular}

Tables 3: Causes of death among autopsied cases with $\mathrm{COHb} \geq 10$

\begin{tabular}{|c|c|c|c|}
\hline \multicolumn{2}{|c|}{ Cause of death } & Number(\%) & $\begin{array}{c}\mathrm{COHb}(\%) \\
\text { Mean }(\mathrm{M}) \pm \text { Standard } \\
\text { deviation }(\mathrm{SD}) \\
\text { Range }\end{array}$ \\
\hline \multicolumn{2}{|c|}{$\mathrm{CO}$ poisoning deaths } & $19(36.5)$ & $\begin{array}{c}\mathrm{M}(43.3) \pm \mathrm{SD}(12) \\
\text { Range(40-65) }\end{array}$ \\
\hline \multirow{4}{*}{ 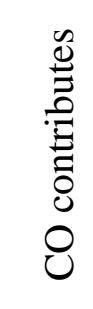 } & Head injury & $1(1.9)$ & 30 \\
\hline & Burn and Carbonization & $10(19.2)$ & $\begin{array}{c}\text { M (36.4) } \pm S D(22.5) \\
\text { Range(15-64) }\end{array}$ \\
\hline & Co poisoning with cardiac comorbidities & $21(40.4)$ & $\begin{array}{c}\mathrm{M}(19) \pm \mathrm{SD}(8.2) \\
\text { Range(10-35) }\end{array}$ \\
\hline & Hyperthermia vehicle entrapment & $1(1.9)$ & 25 \\
\hline \multicolumn{2}{|c|}{ Totals } & $52(100)$ & $\begin{array}{c}\text { M (30) } \pm S D(19.4) \\
\text { Range(10-65) }\end{array}$ \\
\hline
\end{tabular}


Table 4: Place, seasons, and mode of deaths and suggested sources of CO exposure among the autopsied cases with $\mathrm{COHb} \geq 10$

\begin{tabular}{|c|c|c|c|c|c|c|}
\hline \multirow{2}{*}{ Parameter } & \multicolumn{2}{|c|}{ COP } & \multicolumn{2}{|c|}{ CO contributed } & \multicolumn{2}{|c|}{ Total } \\
\hline & Number & $\%$ & Number & $\%$ & Number & $\%$ \\
\hline \multicolumn{7}{|c|}{ A. Place of death } \\
\hline Home & 15 & 78.9 & 18 & 54.5 & 33 & 63.5 \\
\hline Car & 2 & 10.5 & 9 & 27.3 & 11 & 21.2 \\
\hline Workplace & 2 & 10.5 & 3 & 9.1 & 5 & 9.6 \\
\hline \multicolumn{7}{|l|}{ B. Seasons } \\
\hline Autumn & 1 & 5.3 & 3 & 9.1 & 4 & 7.7 \\
\hline Winter & 15 & 78.9 & 23 & 69.7 & 38 & 73.1 \\
\hline Spring & 3 & 15.8 & 1 & 3.0 & 4 & 7.7 \\
\hline Summer & 1 & 5.3 & 5 & 15.2 & 6 & 11.5 \\
\hline \multicolumn{7}{|c|}{ C. Mode of death } \\
\hline Accidental & 18 & 94.7 & 23 & 69.7 & 41 & 78.8 \\
\hline Homicide & 1 & 5.3 & 1 & 3.0 & 2 & 3.8 \\
\hline Suicide & & & 9 & 27.3 & 9 & 17.3 \\
\hline \multicolumn{7}{|c|}{ D. Suspected CO source } \\
\hline Car exhaust & 7 & 36.8 & 3 & 9.1 & 10 & 19.2 \\
\hline $\begin{array}{l}\text { Charcoal } \\
\text { heaters }\end{array}$ & 6 & 31.6 & 1 & 3.0 & 7 & 13.5 \\
\hline Fire & 6 & 31.6 & 9 & 27.3 & 15 & 28.8 \\
\hline Smoking & 0 & 0.0 & 17 & 51.5 & 17 & 32.7 \\
\hline Unknown & 0 & 0.0 & 3 & 9.1 & 3 & 5.8 \\
\hline Totals & 19 & 100.0 & 33 & 100.00 & 52 & 100.00 \\
\hline
\end{tabular}

\section{DISCUSSION}

The current study was conducted to evaluate $\mathrm{COHb}$ levels in autopsied cases in Alqurayyate from 2004 to 2018. During the study years, 461 cases were autopsied. Among them, 54 cases [11.7\%] showed $\mathrm{COHb}$ levels $>10 \%$. Carboxyhemoglobin levels were significantly higher among males and cases blow 30 and above 50 years. COP was reported as a cause of death among 19 [4.1\%] cases while $\mathrm{CO}$ was suggested as a contributing factor in the other 33 deaths. The mode of deaths was reported to be accidental in most of cases. Houses were the most common place of death and most deaths attributed to $\mathrm{CO}$ happened in the winter months. The most common suggested source for exposure to Co was smoking [35.2\%] followed by fires [27.8\%]. Regarding autopsy findings, the external appearance revealed cherry red color red hypostasis in only 14 autopsied cases. The most common findings were pulmonary edema, cerebral edema, and congested lungs [96.2,82.7, and $80.8 \%$ respectively].

Carboxyhemoglobin was expected to be related to $11.7 \%$ of autopsied cases during the studied years. CO poisoning was reported as the direct cause of death in 19 cases [ $4.1 \%$ of the autopsied cases]. It is lower than what was reported in Dammam, the capital of Saudi eastern principality, as CO was 
reported as the direct cause of death among $7.6 \%$ of the autopsied cases during the years from 2004-2013 (de Juniac et al., 2012). However, their study did not considered cases in which CO was suggested as a contributing factor. Data about CO deaths in the other Saudi principalities are deficient. However, in a nearby country, Jordon, COP was reported as a cause of death among $1.8 \%$ of the autopsied cases during the years from 2000-2004 which is lower than our estimated ratio for COP deaths (Hosseininejad et al., 2018). It is clear that COP deaths rates are different among the different cities and in the same city over years.

$$
\text { which may be usually }
$$

misdiagnosed with repeated exposure to the hazardous $\mathrm{CO}$ source or location (Peters et al., 2004).

The current data reported accidental exposure as the most common mode of $\mathrm{CO}$ related deaths and houses were the main places of deaths and winter months are the most common time for COP. This is in accordance with other studies (Girman et al, 1998; Omaye , 2002; de Juniac et al., 2012; Karapirli et al., 2013; Sircar et al., 2015; Hosseininejad et al., 2018). As Co is not commonly used to commit suicide or an assault. In addition, accidental fires and exposure to gas appliances and car exhaust with incomplete combustion are a common source for CO. Houses are the commonest place as they are the most common closed place for exposure to gas appliances as gas heaters and gas stoves. While COP is common in winter months due to higher use of gas heaters and charcoal heaters especially in localities with severe cold as in our research city.

Among cases where COP was considered as a cause of death fires were the commonest sources for $\mathrm{CO}$ [27.8\%]. While the kerosene heaters were suspected to be the first suggested
Carbon monoxide poisoning is more common among males and elderly people, which is on line with the other studies (Girman et al, 1998; Omaye , 2002; de Juniac et al., 2012; Karapirli et al., 2013; Sircar et al., 2015; Hosseininejad et al., 2018). Males are expected to have more outdoor activities with more exposure to $\mathrm{CO}$ sources than females. While elderly population are subjected to have other comorbidities as cardiovascular disorders which may explain higher rates of $\mathrm{CO}$ related deaths as $\mathrm{CO}$ was shown to exacerbate cardiopulmonary diseases even in low levels of exposure

source of $\mathrm{CO}$ among $\mathrm{Co}$ deaths in Jordon [43\%] (Hosseininejad et al., 2018). Other sources were suggested in other studies as gas stoves and water gas heaters (Girman et al, 1998; Karapirli et al., 2013; Sircar et al., 2015). This means that the main source of $\mathrm{CO}$ is different among different communities regrading to their pattern of life and traditional use for the different expected sources of CO. For example, charcoal heaters are commonly used among Saudi people in Alqurayyate, as a community tradition, for heating and it the commonest cause of COP deaths among them in the studied years.

Carbon monoxide was suggested as a contributing factor of death in 33 autopsied cases. Carbon monoxide [CO] was suggested to play a role in cardiac deaths (Tonne et al., 2006; Samoli et al., 2007). In an experimental healthy rats' model, it was shown that $\mathrm{CO}$ can alter calcium handling with the cardiomyocytes with increased sympathetic activity and arrhythmias (Reboul et al., 2017). In addition, in the same rats' ischemic heart model study, $\mathrm{CO}$ was shown to reduce the cardiac contractility at the cardiomyocyte level with associated mitochondrial dysfunction and oxidative damage to 
the cardiomyocytes in the rat's model of ischemic heart (Miziara et al., 2015).

Regarding autopsy findings, the external appearance revealed cherry red colour red hypostasis in about one quarter of autopsied cases, while retinal hemorrhage was found in about 9\% only. The most common findings were pulmonary edema, dark red hypostasis, cerebral edema, congested lungs, and brain hemorrhagic spots were the main findings $(94.4,94.4,79.6,77.8$, and 38.8 respectively). These findings are in accordance with Mehta et al. (2001) who reported deep red discoloration of skin and serous membranes, pulmonary edema, cerebral edema, and brain pinpoint hemorrhages in $80 \%, 100 \%$ and $40 \%$ of the autopsied COP deaths. Cherry red was a fixed finding in other publications about COP deaths autopsy specially among Caucasians (Kumazawa et al., 2000; Jorge DinisOliveira et al., 2010) However, we found its absence is not exclusion for COP and the laboratory investigations for carboxy hemoglobin should be done routinely especially with suggestive history of scene of death as it is also expected that carboxy hemoglobin levels will decline markedly with resuscitation attempts (Ernst et al., 1998).

The current study has some limitations as some cases may be died due to COP but they were not diagnosed or misdiagnosed due to other cases and not autopsied. Also $\mathrm{COHb}$ data may be affected by the resuscitation attempts or time between the exposure and the occurrence of death. Also, $\mathrm{COHb}$ levels do not correlate well with the severity of COP which depends mainly on the dissolved $\mathrm{CO}$ concentration. ${ }^{30} \mathrm{In}$ addition, the duration between death and sampling for $\mathrm{COHb}$ may affect the results.

\section{CONCLUSION}

The current data show that COP remains a direct cause and a contributing cause of death whatever the safety precautions and the advance in mechanical engineering to eliminate its production from the engines and appliances.

\section{RECOMMENDATIONS}

- The public awareness regarding COP and its sources still deficient and more awareness programs should be planed and implemented, mainly before and during the cold months.

- COHb levels should be routinely estimated in the autopsied cases, especially with suggestive history.

- Mostly postmortem signs as cherry red colour and retinal hemorrhages are not found in all cases with high $\mathrm{COHb}$ levels. This should not mislead the forensic examiner and he should ask for $\mathrm{COHb}$ levels in $\mathrm{COP}$ suspicious cases

\section{REFERENCES}

Aldossary, M.; Almadni, O.; Kharoshah, M.; Alsaif, D.,; Alsowayigh, K. and Alfaraidy, M. (2015): Carbon monoxide toxicity in Dammam, KSA: Retrospective study. Egypt J Forensic Sci, 5(1):36-8.

Andre, L.; Boissière, J.; Reboul, C.; Perrier, R.; Zalvidea, S.; Meyer, G. and et al. (2010): Carbon monoxide pollution promotes cardiac remodeling and ventricular arrhythmia in healthy rats. American journal of respiratory and critical care medicine, 181(6):587-95.

Battah, A.H.; Al-Farras, M.I.; Abdallat, I.M. and Hadidi, M.S. (2009): Trends of carbon 
monoxide fatalities in Jordan. Saudi med J., 30(6):853-4.

CDC (2007): Carbon monoxide-related deaths-United States, 19992004. Morb Mortal Wkly Rep. 2007;56(50):1309-1312.

Cobb, N. and Etzel, R.A. (1991): Unintentional carbon monoxideRelated deaths in the United States, 1979 through 1988. Jama., 266(5):659-

de Juniac, A; Kreis, I.; Ibison, J. and Murray, V. (2012): Epidemiology of unintentional carbon monoxide fatalities in the UK. Int J Environ Health Res., 22(3):210-9.

Ernst, A. and Zibrak, J.D. (1998): Carbon monoxide poisoning $\mathrm{N}$ Engl J Med., 339(22):1603-1608.

Ghosh, R.E; Close, R.; McCann, L.J.; Crabbe, H.; Garwood, K.; Hansell, A.L. and et al. (2015): Analysis of hospital admissions due to accidental non-fire-related carbon monoxide poisoning in England, between 2001 and 2010. J Public Health. 38(1):76-83.

Girman, J.R..; Chang, Y.L.; Hayward, S.B. and Liu, K.S. (1998): Causes of unintentional deaths from carbon monoxide poisonings in California. Western journal of medicine. 168(3):158.

Hampson, N.B and Weaver, L.K. (2007): Carbon monoxide poisoning: a new incidence for an old disease. Undersea Hyperb Med., 34:163-168.

Hosseininejad,

S.M.; Aminiahidashti, H.; Khatir, I.G.; Ghasempouri, S.K.; Jabbari, A. and Khandashpour, M. (2018): Carbon monoxide poisoning in Iran during 1999-2016: A systematic review and meta-analysis. Journal of forensic and legal medicine. 2018 Jan 1;53:87-96.

Jorge Dinis-Oliveira, R.; Carvalho, F.; Magalh ÃEs, T. and Santos, A. (2010): Postmortem changes in carbon monoxide poisoning. Clinical Toxicology, 48(7):762-3.

Karapirli, M.; Kandemir, E.; Akyol, S., Kantarci, M.N.; Kaya M. and Akyol, O. (2013): Forensic and clinical carbon monoxide (CO) poisonings in Turkey: A detailed analysis. Journal of forensic and legal medicine, 20(2):95-101.

Kreuzer, L.B; Kenyon, N.D. and Patel CK. (2009): Air pollution: sensitive detection of ten pollutant gases by carbon monoxide and carbon dioxide lasers. Science. 1972 Jul 28;177(4046):347-9. L.K. Weaver. Carbon monoxide poisoning. N Engl J Med., 360(12):1217-25.

Kumazawa, T.; Watanabe-Suzuki, K.; Seno, H.; Ishii, A. and Suzuki, O. (2000): A curious autopsy case of accidental carbon monoxide poisoning in a motor vehicle. Legal Medicine. 2(3):1815.

Lippi, G.; Rastelli, G.; Meschi, T.; Borghi, L. and Cervellin, G. (2012): Pathophysiology, clinics, diagnosis and treatment of heart involvement in carbon monoxide poisoning. Clin Biochem, 45(1617):1278-85.

Luchini, P. D.; Leyton, J. F.; Strombech, M. D. L. C.; Ponce, J. C.; Jesus, M. D. G. S. and Leyton, V. (2009): Validation of a spectrophotometric method for quantification of carboxy- 
hemoglobin. Journal of analytical toxicology, 33(8), 540-544.

Mehta, S.R.; Niyogi, M.; Kasthuri, A.S.; Dubal, U.; Bindra, S.; Prasad, D. and et al. (2001): Carbon monoxide poisoning. J Assoc Physicians India., 49 :622625.

Miziara, I.D.; Razaboni, R.S.; Miziara, C.S.; Moraes, W.S; Ramacciotti, H.R.; Mielli, A.,C. and et al. (2015): Misinterpretation of Hypostasis Does not Identify Death from Carbon Monoxide Poisoning and Does not Avoid another Five Deaths. Austin J Forensic Sci Criminol., ;2(3):1028.

Omaye, S.T. (2002): Metabolic modulation of carbon monoxide toxicity. Toxicology, 180(2):13950.

Peters, A.;Von Klot, S.; Heier, M.; Trentinaglia, I.; Hörmann, A.; Wichmann, H.E. and et al. (2004):. Exposure to traffic and the onset of myocardial infarction. New England Journal of Medicine, 351(17):1721-30.

Raub, J.A.; Mathieu-Nolf, M.; Hampson, N.B. and Thom, S.R. (2000): Carbon monoxide poisoning - a public health perspective. Toxicology, 145(1):14.

Reboul, C.; Boissière, J.; André, L.; Meyer, G.; Bideaux, P.; Fouret, G. and et al. (2017): Carbon monoxide pollution aggravates ischemic heart failure through oxidative stress pathway. Scientific reports, 7:39715.

Zhu, B.L.; Ishikawa, T.; Michiue, T.; Li, D.R.; Zhao, D.; Oritani, S.;
Samoli, E.; Touloumi, G.; Schwartz, J.; Anderson, H.R.; Schindler, C.; Forsberg, B. and et al. (2007): Short-term effects of carbon monoxide on mortality: an analysis within the APHEA project. Environmental Health Perspectives, 115(11):1578-83.

Sircar, K.; Clower, J.; kyong Shin, M.; Bailey, C.; King, M. and Yip, F. (2015): Carbon monoxide poisoning deaths in the United States, 1999 to 2012. Am J Emerg Med., 33(9):1140-5.

Sircar, K.; Clower, J.; kyong Shin, M.; Bailey, C.; King, M. and et al. (2015): Carbon monoxide poisoning deaths in the United States, 1999 to 2012. The American journal of emergency medicine, 33(9):1140-5.

Statista (2017): Number of deaths from unintentional carbon monoxide poisoning in the United Kingdom (UK) from 1995 to 2016, by month. https://www.statista. com/statistics/561679/deathsfrom-unintentional-carbonmonoxide-poisoning-uk/ (accessed 27 January, 2019)

Tonne, C.; Melly, S.; Mittleman, M.; Coull, B.; Goldberg, R.; Schwartz, J. (2006): A casecontrol analysis of exposure to traffic and acute myocardial infarction. Environmental health perspectives. 115(1):53-7.

Varon, J.; Marik, P.E; Fromm, Jr. R. E. and Gueler, A.(1999): Carbon monoxide poisoning: a review for clinicians. J Emerg Med., ;17(1):87-93.

Kamikodai, Y. and et al. (2006): Postmortem cardiac troponin $\mathrm{T}$ 
levels in the blood and pericardial fluid. Part 1. Analysis with special regard to traumatic causes of death. Legal Medicine., 8(2):86-93. 


\section{الـمـلـهص الـهـربـي}

الـوفـــات الـمـرتـبـة بـأول أكسيـد الـكربـون فـي مـحـافظة الـقـريـات ، بـالـمـمـكة الـعـربـيـة الـسعـوديـة فـى الـفـــرة مـن

\section{$r \cdot 11 \quad r \quad r \cdot \varepsilon$}

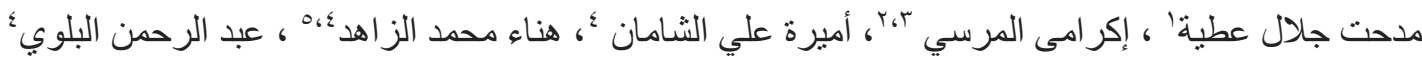
'مركز الطب الثرعي ، مديرية الثؤون الصحية بالقريات ، المملكة العربية السعودية ، ثقم الطب الثرعي و السموم الإكلينيكية، كلية طب المنصورة ، مصر ، “ّقم الأمر اض ، كلية الطب ، جامعة الحدود الثمالية ، عرعر ، المملكة العربية السعودية ، عمركز تبوك لمر اقبة السموم ، مديرية الثؤون الصحية بالقريات مديرية الثؤون الصحية بتبوك، المملكة العربية السعودية ، ؛ قسم الطب الثرعى و السموم ، كلية الطب ، جامعة القاهرة ، مصر.

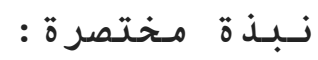

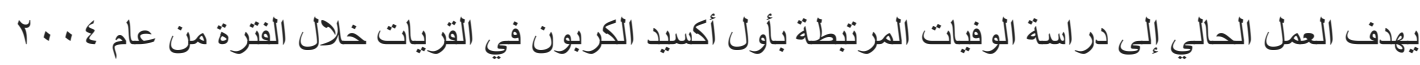

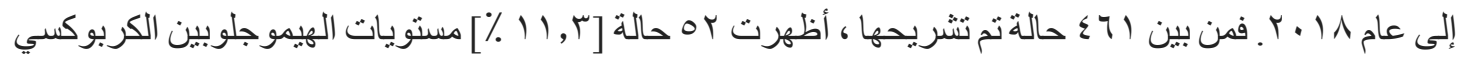
> 10 ٪. وقد كانت مستويات الهيموجلوبين الكربوكسي المرتفعة أكثر شيوعًا بين الذكور و الثباب و المسنين

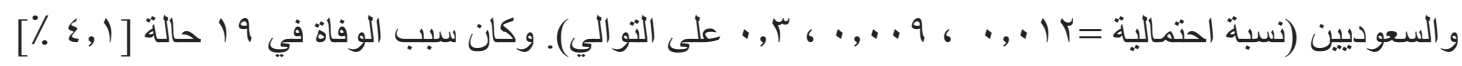

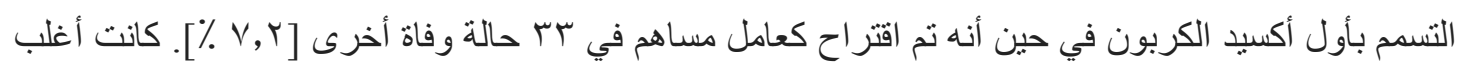

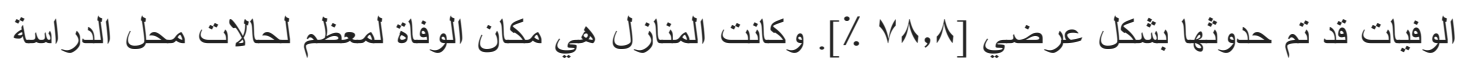

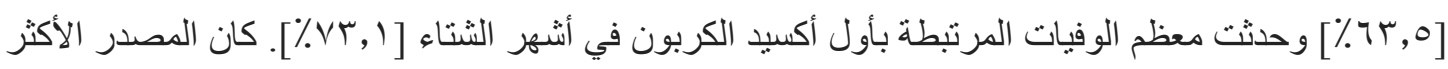

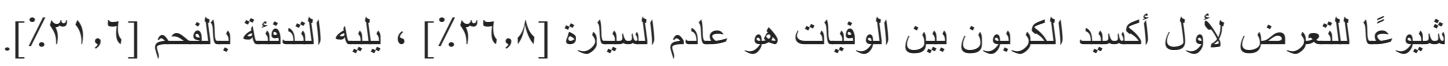
وفيما يتعلق بنتيجة تتريح الجثة ، فقد كثف فحص المظهر الخارجي عن ان لون الكرز الأحمر للرسوب الدموى قد لوحظ في 9, ج ٪ فقط من الحالات التسمم بأول أكسيد الكربون وبينما كانت النتائج الأكثر شيوعًا هي الوذمة

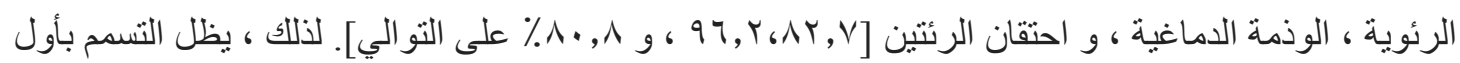
أوكسيد الكربون سبيًا شائعًا للوفاة ، على الرغم من احتياطات السلامة. لذا يوصى بمزيد من بر امج التوعية العامة حول التسمم بأول أوكسيد الكربون. وأيضًا ، يجب تقدير مستويات الهيموجلوبين الكربوكسي بشكل روتيني في الحالات التي يتم فيها تشريح الجثث ، خاصةً مع وجود شبهة للتعرض لمصدر من مصادره. 